\title{
Natasha Sumner and Aidan Doyle, eds., North American Gaels: Speech, Story, and Song in the Diaspora (Montreal and Kingston: McGill-Queen's University Press, 2020). 512 pp. Cloth \$130.00, Paperback \$45.95.
}

\begin{abstract}
North American Gaels: Speech, Story, and Song in the Diaspora, edited by Natasha Sumner and Aidan Doyle, is a vast exploration of the languages of the Gaelic diaspora from the eighteenth to the twentieth century. It contains two sections, one each for the Irish and Scottish halves of the Gaelic world, and explores the history of Gaelic language, folklore, poetry, prose, music, and myth. The purpose of this collection is to begin to fill a scholarly gap in the study of the languages of the Gaelic diaspora (1-2). The contributors to this volume bring the often underused but all too necessary knowledge of Gaelic dialects in order to "make informed judgements" about the language and motivations behind its many uses (1). The goal of both the editors and the contributing authors of North American Gaels is to bring attention to the present scholarship done by linguistic historians while revealing the work still to be done (20).
\end{abstract}

The introduction provides historical background on the similarities and differences between Irish and Scottish Gaels. Irish Gaels arrived in North America in the eighteenth century, but it was not until the mass migration of the mid-to-late nineteenth century that the Irish language had a greater presence on the continent (10). The language struggled to put down roots in the New World for reasons not fully understood, thus the linguistic history of Irish Gaels has proved difficult to uncover. Yet, periods of Irish cultural revival during the late-nineteenth century left some Irish Gaelic sources for scholars to ponder (11). The case was different for Scottish Gaels, as their dialect was used from generation to generation as a "community language" (12-13). This was due in part to the fact that many Scottish Gaels settled in large groups in rural areas, which allowed for the dialect to flourish postmigration (14).

The first section of North American Gaels addresses the Irish Gaels. Tomás 'O hÍde's article, "Irish-Language Folklore in An Gaodhal," is an excellent example of the dual mission of this volume to highlight and inspire scholarship. 'O hÍde explains that the Brooklyn periodical An Gaodhal (The Gael) was one of the only nineteenth-century settings in which supporters and readers of the Irish language could explore the language and its folklore (135). American and Irish authors contributed to the periodical, and 'O hÍde argues that $A n$ Goadhal provided a method by which a "general audience" could access Irish folklore, and that surviving copies of the publication are both a rare Irish-language source in North America and a point of pride for the community (154). What is most interesting about this chapter is that 
'O hÍde provides an example of the folklore from $A n$ Gaodhal with both Irish Gaelic and English versions of "Eachtra Eoghain Ruadh Anseo thíos" or "The Adventure of Eoghan Rua Here below." This allows the fun and charm of folklore to speak for itself while 'O hÍde provides English translation and historical context.

Matthew Knight's contribution, "Forming and Training an Army of Vindication: The Irish Echo, 1886-1894," argues the Irish Echo, an Irish-American newspaper based in Boston, helped to "forge a new Irish identity in the United States," and supported a generation of Irish nationalists during the late-nineteenth century (183). Knight explains the history of the publication by separating its history into three eras according to the tenure of its three editors, P.J. O'Daly, Michael O'Shea, and Charles O'Farrell. While each of the three editors had differences in their management of the paper, all shared a desire to promote the merits of Irish literature against those, mostly English, critics who doubted its quality, even its existence (164, 183). Knight also argues that scholars ought to wonder less whether the short-lived publication succeeded or failed and think more on the impact of the publication on the Irish-American community.

The second half of North American Gaels concerns Scottish Gaels. Two of the chapters in this section are Robert Dunbar's 'John MacLean's 'New World' Secular Songs: A Poet, His Print Editors, and Oral Tradition” and Lorrie MacKinnon's "Annie Johnston in Nova Scotia." Dunbar analyzes the early-nineteenth-century poet and song-writer John MacLean's work and argues MacLean, like present scholars, understood the need to transcribe oral traditions in order to preserve them in the face of rapid change. Dunbar further posits that written versions of oral traditions may themselves be taken as authoritative, thereby impacting the oral traditions $(281,282)$. John MacLean, a Scottish migrant to Nova Scotia, transcribed and published his own work, as did his grandson Alexander MacLean Sinclair $(282,287)$. However, the two men translated the same Gaelic words differently, and Dunbar provides several examples as proof (301). Dunbar's purpose in revealing the differences between the two translations is to encourage scholars to be aware of the impact that transcribers and editors have on the process of transferring oral traditions into text, and that the people and perspectives behind the process may be as revealing, and impactful, as the oral traditions themselves.

Lorrie MacKinnon's chapter highlights the connections sustained across the Atlantic between Nova Scotia and Scotland, many of which were embodied in the passionate work of Annie Johnston (424). Johnston lived in Scotland, but maintained a lively correspondence with the Scottish communities of Nova Scotia, and visited several locations in the province in 1954 (424-426). The chapter chronicles Johnston's journey among the Scots in Nova Scotia via her correspondence with friends, during which she recorded their folklore and songs in order to preserve them (428). The purpose of MacKinnon's chapter is twofold: to highlight the importance of the linguistic preservation done by Annie Johnston, and to opine that those who preserved these cultural artifacts are worthy of study in their own right (434). 
These four chapters are representative of the many fascinating and thought-provoking contributions found in North American Gaels. Throughout, the work done by the contributors to include both Gaelic and English versions of the many stories, songs, poems, and articles of the Gaelic diaspora allows readers to appreciate the language, and those who spoke and wrote it, whether or not they have the language skills to read them in their original language. The editors and contributors to North American Gaels achieved their goals to both highlight scholarship and to encourage it, and produced an informative and accessible work while doing so.

Erin Barr

Purdue University 